\title{
Crosstalk between Stress Granules, Exosomes, Tumour Antigens, and Immune Cells: Significance for Cancer Immunity
}

\author{
Vinoth Kumar Kothandan ${ }^{1} \oplus$, Sangeetha Kothandan ${ }^{2}$, Do Hee Kim ${ }^{3}$, Youngro Byun ${ }^{4,5}$, \\ Yong-kyu Lee ${ }^{6}$, In-Kyu Park ${ }^{7}$ (D) and Seung Rim Hwang ${ }^{1,8, *(D)}$ \\ 1 Department of Biomedical Sciences, Graduate School, Chosun University, 309 Pilmun-daero, Dong-gu, \\ Gwangju 61452, Korea \\ 2 Department of Industrial Biotechnology, Bharath Institute of Higher Education and Research, \\ Chennai 600073, India \\ 3 Department of Bioengineering, College of Engineering, Hanyang University, 222 Wangsimni-ro, \\ Seongdong-gu, Seoul 04763, Korea \\ 4 College of Pharmacy, Seoul National University, 1 Gwanak-ro, Gwanak-gu, Seoul 08826, Korea \\ 5 Department of Molecular Medicine and Biopharmaceutical Sciences, Graduate School of Convergent Science \\ and Technology, Seoul National University, 1 Gwanak-ro, Gwanak-gu, Seoul 08826, Korea \\ 6 Department of Chemical and Biological Engineering, Korea National University of Transportation, \\ 50 Daehak-ro, Chungju, Chungbuk 27469, Korea \\ 7 Department of Biomedical Sciences, Chonnam National University Medical School, 322 Seoyang-ro, \\ Hwasun 58128, Korea \\ 8 College of Pharmacy, Chosun University, 309 Pilmun-daero, Dong-gu, Gwangju 61452, Korea \\ * Correspondence: srhwang@chosun.ac.kr; Tel.: +82-62-230-6365
}

Received: 29 February 2020; Accepted: 4 April 2020; Published: 8 April 2020

\begin{abstract}
RNA granules and exosomes produced by tumour cells under various stresses in the microenvironment act as critical determinants of cell survival by promoting angiogenesis, cancer metastasis, chemoresistance, and immunosuppression. Meanwhile, developmental cancer/testis (CT) antigens that are normally sequestered in male germ cells of the testes, but which are overexpressed in malignant tumour cells, can function as tumour antigens triggering immune responses. As CT antigens are potential vaccine candidates for use in cancer immunotherapy, they could be targeted together with crosstalk between stress granules, exosomes, and immune cells for a synergistic effect. In this review, we describe the effects of exosomes and exosomal components presented to the recipient cells under different types of stresses on immune cells and cancer progression. Furthermore, we discuss their significance for cancer immunity, as well as the outlook for their future application.
\end{abstract}

Keywords: stress; exosome; cancer; immunotherapy; cancer/testis antigen

\section{Introduction}

The tumour microenvironment consists of components, including cancer-associated fibroblasts (CAFs), immune-inflammatory cells, adipose cells, neuroendocrine cells, lymphatic vascular networks, and the extracellular matrix (ECM) [1]. Given the complex interplay between cells and the surrounding ECM, genetic or epigenetic alterations occur in cancers [2]. Among the hallmarks of cancer, the dysregulation of cellular signal transduction has significant characteristics, because proteins involved in signalling pathways, such as tyrosine kinase, GTPase, cytoplasmic serine-threonine kinase, and lipid kinase are genetically altered. In addition, cancer/testis (CT) antigens, which are generally expressed only in male germ cells, are aberrantly expressed in cancer and mediate the malignant 
phenotype [3]. Malignant tumour cells show continuous cell growth and division, resisting cell death and promoting angiogenesis, invasion, and metastasis [4]. They interact with heterotypic stromal cells by the release of extracellular vesicles (EVs) and the expression of signalling molecules for their survival and expansion [5].

When cells transformed into cancer cells are in an environment lacking oxygen and nutrients, RNA granules appear in the cytoplasm and regulate post-transcriptional gene expression [6]. In recent years, stress granules (SGs) have been identified as a promising target for the treatment of cancer, because the components involved in cancer cell physiology are often up-regulated in SGs and help the cancerous cells survive under the hostile microenvironment [7].

Under various stress conditions in the microenvironment, exosomes released from tumour cells promote progression of cancer metastasis [8,9]. Exosomes are nanovesicles released into the extracellular environment via the endosomal vesicle pathway by the fusion of a multivesicular body (MVB) with the cellular plasma membrane [10]. They contain a wide range of mRNAs, microRNAs (miRNAs), DNAs, and proteins, and their molecular composition varies according to the mechanism of formation, as well as the type or functional state of the donor cells [11]. Exosomes isolated from malignant effusions contain tumour antigens, such as human epidermal growth factor receptor 2 (HER2)/neu from ovarian cancer ascites and protein melan-A from melanoma patients [12,13]. In the tumour microenvironment, tumour-derived exosomes (TEXs) can interact not only with neoplastic cells but also with immune cells, thus modulating the anti-tumour immune response and affecting tumour progression [14]. Intercellular communication occurs in receptor-ligand interactions between membrane-bound proteins on exosomes and the corresponding receptors on the cell surface, followed by the activation of signalling, in cellular uptake of exosomes through phagocytosis, or in the direct fusion of exosomes with the cell membrane [15].

Exogenous anticancer therapies, as well as endogenous stressors in the tumour microenvironment, such as thermal stress, hypoxia, acidosis, and reactive oxygen species (ROS), trigger EV formation, resulting in the evolution of the microenvironment [16]. Exosomes carrying heat shock proteins (HSPs) from reticulocytes, peripheral blood mononuclear cells (PBMCs), B cells, and carcinoma cells have been reported to modulate immunological responses [17]. Tumour hypoxia, a stress condition where tumour cells are deprived of an oxygen supply, increases production and growth factor contents of exosomes, thereby promoting angiogenesis, invasion, and metastasis [18]. When disruption of EV membranes occurs in acidosis, vascular endothelial growth factor (VEGF) in the vesicles can be released and transferred to the recipient cells [19]. The contents of mRNA were also changed in the presence of oxidative stress, as demonstrated in mast cells, suggesting that the function of tumour-associated EVs can be altered by stress conditions [20]. The NKG2D transmembrane receptor on cytotoxic lymphocytes recognizes NKG2D ligands, which are induced during cellular stress. In malignant stages, however, cancer cells release NKG2D ligand-expressing exosomes as decoys for down-regulating the cognate receptor and impairing the NKG2D-mediated cytotoxic response [21].

While exosomes exposed to stress act as conveyors for tumour progression, they also exhibit delicate bystander effects [22]. Thus, utilizing these tumour-modulating effects of exosomes or customisation together with different immunotherapeutic approaches could be a promising way to treat cancer. One of the immunotherapeutic approaches is the activation of DNA damage response (DDR) for the clearance of senescent cancer cells by natural killer (NK) cells [23]. Targeting immunogenic cell death damage (danger)-associated molecular patterns (DAMPs) can be a strategy for strengthening the efficacy of cancer immunotherapy [24]. When intracellular biomolecules from the host are exposed outside the cells because of stress, tissue injury, or necrosis, they can be recognised as DAMPs through immune cell receptors [25]. Thus, DAMPs can initiate the innate immune system, including NK cells, and induce an adaptive $\mathrm{T}$ cell immune response by promoting the maturation of dendritic cells (DCs) and the presentation of antigens associated with dead tumour cells [26]. Various types of DAMPs, such as HSPs, high-mobility group box 1, DNA, and RNA have been reported to act as ligands of 
pattern recognition receptors and trigger signalling [27]. Immunogenic CT antigens overexpressed in malignancies have also been recognized as clinical targets for cancer immunotherapy [28].

In this review, the influence of different stresses on RNA granules or exosomes and their interaction with immune cells, including DCs, macrophages, T cells, and NK cells will be described (Figure 1). The possible strategies for cancer immunotherapy, based on the components of SGs and exosomes together with CT antigens will also be discussed. The dysregulation of cellular signal transduction resulting from genetic alteration in proteins in the microenvironment would have significance for gametogenesis and cancer immunity.

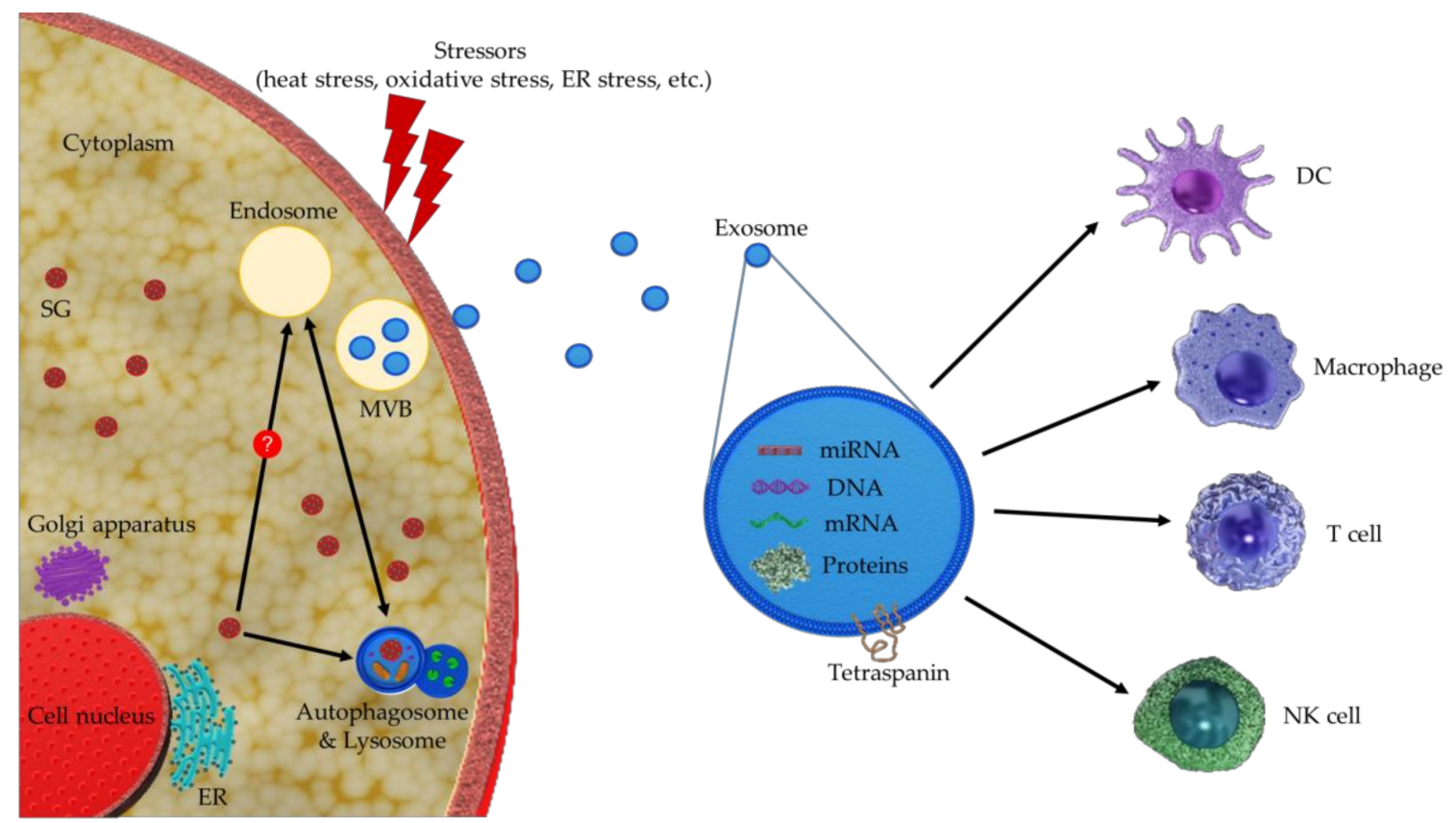

Figure 1. The outline of crosstalk between stress granules (SGs), exosomes, and immune cells. ER: endoplasmic reticulum; MVB: multivesicular body; miRNA: microRNA; DC: dendritic cell; NK: natural killer.

\section{SGs and RNA-Binding Proteins (RBPs) in the Tumour Microenvironment}

SGs are the non-membranous, dense aggregation formed in the cytoplasm under different types of environmental stress [29]. After the initial stress in the cancer microenvironment is sensed by eukaryotic initiation factor (eIF)-2 $\alpha$ kinases, such as general control nonderepressible-2, heme-regulated inhibitor, protein kinase R (PKR), and PKR-like endoplasmic reticulum kinase (PERK), SG formation is triggered [30]. Subsequently, it aids in the adaptation and survival of tumour cells, which are exposed to the increased demand for oxygen and nutrients during solid tumour development [31]. The exposure of tumour cells to an environment that induces suboptimal states, such as hypoxia and nutrient deprivation, stimulates neovascularisation and dysregulation of endoplasmic reticulum (ER) protein folding in the cells [31,32]. In addition to these conditions, aerobic glycolysis by tumour cells further develops ER stress and results in high oxidative stress, because of the accumulation of ROS (Scheme 1) [33]. 


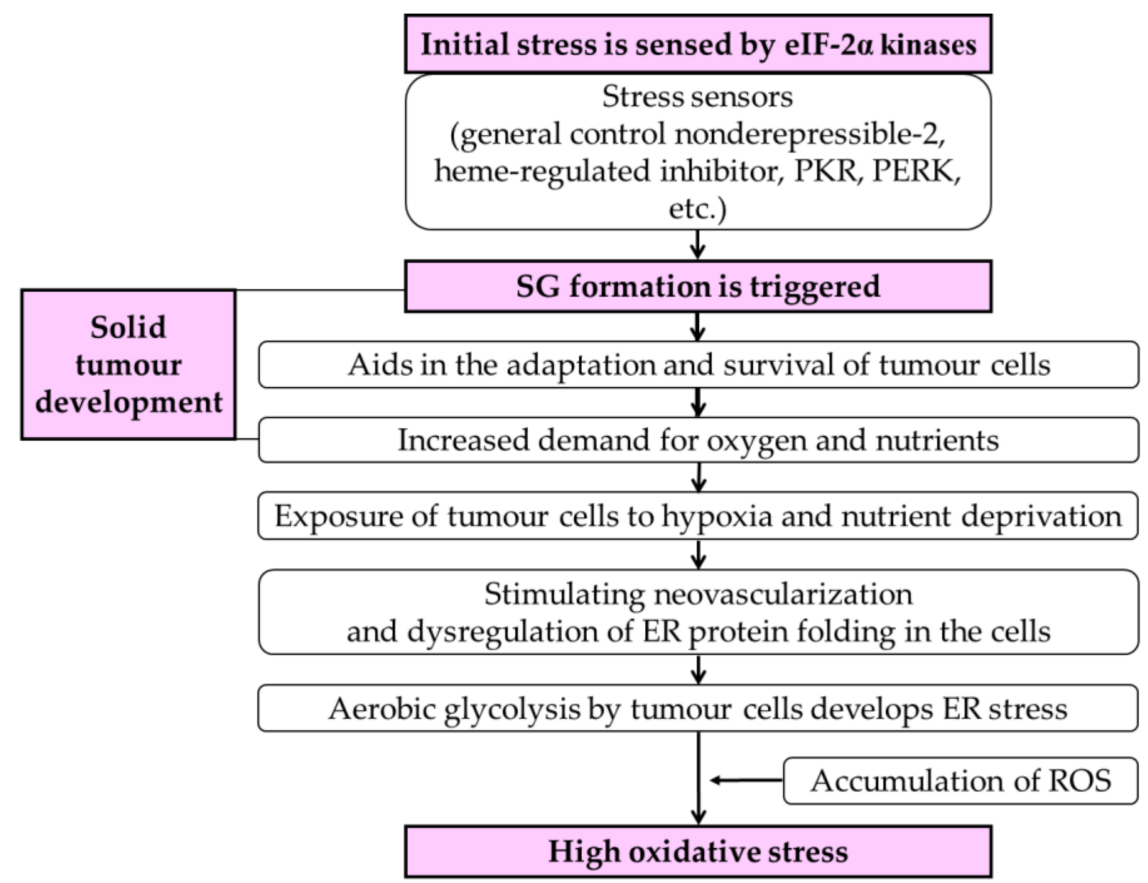

Scheme 1. Schematic representation of the different stress pathways involved in the cancer microenvironment. eIF: eukaryotic initiation factor; PKR: protein kinase R; PERK: PKR-like endoplasmic reticulum kinase; SG: stress granule; ER: endoplasmic reticulum; ROS: reactive oxygen species.

As a result of phosphorylation of eIF- 2 by stress, polysomes are disassembled and stalled messenger ribonucleoprotein particles arise in the cytoplasm [34]. These consist of translation initiation factors, $40 \mathrm{~s}$ ribosomal subunits, and $48 \mathrm{~S}$ complexes, as well as a subset of RNA-binding proteins (RBPs associated with mRNA as the main requirement for SG assembly, and subsequently, for the recruitment of other signalling molecules $[35,36]$.

Critical roles of RBPs in SG assembly are evidenced by studies on the mutations of RNA recognition motifs and studies on the overexpression of RBPs, such as Ras GTPase-activating protein, $\mathrm{SH} 3$ domain binding protein (G3BP), and T-cell-restricted intracellular antigen 1 (TIA1) $[37,38]$. Further evidence has shown that the small-interfering RNA (siRNA)-mediated knockdown of TIA1, TIA1-like 1 (TIAL1 or TIAR), and G3BP1 significantly interferes with SG formation, despite the phosphorylation of eIF-2 [39]. The shuttling of RBPs in and out of SGs was confirmed by fluorescence recovery after photobleaching [40]. SGs are assembled by the shuttling of TIA1 with mRNA and equilibrate to polysomes dynamically [41]. Serine/arginine-rich splicing factor 3 protein also plays a role in SG assembly, because it is associated with 40 s ribosomal subunits and the regulation of cytoplasmic post-transcriptional mRNA, as well as RNA splicing in the nucleus [42].

Y-box binding protein (YB)-1 with cold shock domain is also one of the protein components localised to SGs. It regulates SG formation by directly binding to the $5^{\prime}$ untranslated region (UTR) and activating translation of the mRNA encoding G3BP1 [43]. YB-1 expressed in the angiogenic endothelial cells of tumours serves as a transcriptional regulator, and silencing of YB-1 using siRNA significantly prevents growth factor-dependent cell growth [44]. YB-1 mRNA transcripts are regulated by the mammalian target of rapamycin (mTOR) complex 1 , which contributes to tumour invasion and metastasis [45]. Increased levels of YB-1 alters the cellular localisation of membrane type 1 matrix metalloproteinase and activates the translation of mRNAs that mediate the epithelial-mesenchymal transition in breast carcinomas [46,47]. It is also correlated with poor prognosis or patient survival, as well as multidrug resistance-1 gene transcription [48,49]. This suggests that YB-1 is a potential target for cancer treatment. Additionally, YB-1 plays multifunctional roles, such as receptor activation, translation of oxidative phosphorylation mRNAs, and participation in the inflammatory processes [50-52]. 
It is worth noting that cytosolic YB-1 protein has been reported to be present in exosomes derived from the human embryonic kidney (HEK) 293 cells, and to recognise specific exosomal RNA motifs [53]. YB-1, which forms a complex with mRNA, can be transported out of the donor cell by YB-1-enriched vesicles, and can play a role in modulating target gene expression in the recipient cells [54,55].

The proteolytic cleavage of YB-1 can be controlled by the 20S proteasome [56]. It is important in YB-1 functions under stress, and thus, modulating proteolytic cleavage of YB-1 in the cancerous site could affect cell proliferation, invasion, and migration of immune cells.

\section{Influence of Exosomes Released under Stress on the Tumour Microenvironment}

\subsection{Exosomes Released from Cells Under Heat Stress}

Exosomes include chaperone HSPs (e.g., Hsp60, Hsp70, Hsp84, and Hsp90), major histocompatibility complex (MHC) for antigen presentation and T cell stimulation, apoptosis-linked gene-2 interacting protein X (ALIX) or tumour susceptibility gene 101 for MVB formation, signal transduction proteins, adhesion molecules, cytoskeletal proteins, enzymes, and tetraspanins [57]. Stressors in the tumour microenvironment have been reported to change RNA or protein composition of exosomes and promote the release of exosomes [58]. Heat stress or hyperthermia activates the immune system and promotes granulocytic infiltration into the tumour site, which contributes to the control of tumour growth in vivo [59]. It might enrich intracellular chemokines in lipid rafts and increase the mobility of chemokines into exosomes via a lipid raft-dependent pathway [60]. Heat stress induces the expression of chemokines in TEXs, and chemotaxis may occur by the interaction of chemoattractive TEXs with DCs, activating T cells. Extracellular ATP release and calcium influx regulating vesicle transport are increased by heat treatment, which stimulates the release of exosomes from cells $[61,62]$.

TEXs under heat stress have been reported to influence antitumour immunity in vitro and in vivo [63]. DCs incubated with TEXs under heat stress stimulated T cell proliferation and cytotoxic T lymphocyte (CTL) activity more efficiently than DCs incubated with untreated exosomes did in vitro. In heat-stressed exosomes from ascites of gastric adenocarcinoma patients, levels of Hsp60 and Hsp70 were higher than in stress-free exosomes [64]. Heat-stressed TEXs carrying carcinoembryonic antigens induced a tumour-specific CTL response and inhibited tumour progression in the colorectal adenocarcinoma mouse model more efficiently than TEXs without heat treatment [65]. HSPs upregulated by heat stress can be packed into exosomes and bind tumour antigens, leading to antigen cross presentation [66]. Hsp70 release from PBMCs under heat shock was reportedly dependent on exosomes rather than lipid rafts [67].

\subsection{Exosomes Released from Cells under Oxidative Stress or Hypoxia}

Oxidative stress induced by the imbalance between the level of ROS and detoxication ability triggers SG formation, and malignant tumour development is promoted by the increased production of certain ROS [68]. Hypoxia, a deficiency in the concentration of oxygen, also contributes to tumour aggressiveness and metastasis through hypoxia-inducible factor (HIF), leading to changes in metabolic pathways [69]. During oxidative stress or hypoxia triggered by tumour cells, the autophagy process in adjacent CAFs is induced with the aid of HIF- $1 \alpha$, and damaged proteins or organelles are removed [70,71]. EVs secreted from hypoxic tumour cells mediate the crosstalk between tumour cells and stromal cells in the tumour microenvironment [72,73]. Through the interaction, they can influence tumour angiogenesis, invasion, metastasis, and the immune system [74].

According to the donor cells, the content of exosomes under hypoxia vary in transcription factors, non-coding RNAs, mRNAs, fatty acids, and other proteins [75]. Upregulation of different miRNA expression has been reported in exosomes derived from various tumours under hypoxic stress [76]. Exosomes secreted from pancreatic cancer cells highly express miR-301a-3p under hypoxia and polarise anti-inflammatory M2 macrophages via phosphatase and tensin homolog (PTEN) downregulation 
and phosphoinositide 3-kinase (PI3K)- $\gamma$ activation. M2 polarisation of macrophages incubated with hypoxic exosomes can be confirmed by M2 markers, such as cluster of differentiation (CD) 206, CD163, interleukin (IL)-10, transforming growth factor (TGF)- $\beta$, and arginase-1. Exosomal miR-301a-3p, which is dependent on HIF- $1 \alpha$ and HIF- $2 \alpha$, leads to the enhanced invasion and metastasis of pancreatic cancer cells in vitro and in vivo [77]. Delivery of miR-25-3p by hypoxic exosomes also promotes IL-6 expression from macrophages; toll-like receptor (TLR)-dependent, nuclear factor, $\mathrm{k}$-light-chain-enhancer of activated B cells (NF- $\mathrm{KB}$ ) activity; and migration of normoxic breast cancer cells [78].

The hypoxic condition in carcinoma tissue is correlated with proteins, which reduce cell adhesiveness and enhance invasion or migration of tumour cells [79]. Proteases, IL-1, VEGF, platelet-derived growth factor-BB, S100 calcium-binding protein A4, angiogenin, and granulocyte-macrophage colony-stimulating factor (GM-CSF) are secreted, according to quantitative analysis of the secretome from A431 tumour cells under hypoxia and reoxygenation [80]. More than $40 \%$ of the secretomes from hypoxic carcinoma cells were found to be exosome-associated cytosolic proteins, including tetraspanins and ALIX, and to have the potential for activating the proteolytic system, angiogenesis, and metastasis. This suggests that exosomal cargo protein contents changed under hypoxic stress affect the transcriptome of recipient cells and enable tumour cells to overcome the hostile microenvironment. Exosomes derived from hypoxic glioma cells included neovascularisation-regulating proteins and increased the tube formation or branching intervals in endothelial progenitor cells, possibly via the upregulation of small nucleolar RNA and downregulation of the voltage-gated potassium channel gene [81].

Hypoxic tumour cells secrete exosomes carrying TGF- $\beta$, resulting in immunosuppression through the accumulation of regulatory $\mathrm{T}$ (Treg) cells and activation of CAFs [82]. TEXs containing NKG2D ligands under hypoxic stress impair the cytolytic functions of NK cells via the downregulation of NKG2D receptors [83]. Moreover, chemoattractants, such as colony-stimulating factor (CSF)-1 and ferritin heavy/light chains, are enriched in exosomes secreted from hypoxic tumour cells, which contribute to monocyte recruitment and macrophage differentiation [84,85]. The differentiation of monocytic cells to M0-like macrophages and their polarisation to M2 macrophages were supported by the exosomal cargo from human melanoma, epidermoid carcinoma, and lung cancer cells under hypoxic stress [85]. The treatment of hypoxic exosomes also induced stem cell differentiation, which was confirmed by $\mathrm{F} 4 / 80^{+} \mathrm{CD} 135^{\text {high }}$ positive cell populations in bone marrow-derived macrophages (BMMs). In addition, let-7a miRNA enriched in hypoxic TEXs inhibited the insulin-protein kinase B (AKT)-mTOR signalling pathway, leading to enhanced mitochondrial oxidative phosphorylation of BMMs.

Overall, the detailed analysis of hypoxic tumour cells and TEXs in cancer biology have provided positive signs for the angiogenesis, invasion, metastasis, and progression of cancer through the abnormal expression of specific proteins or RNAs, but have a negative effect on anticancer immunity.

\subsection{Exosomes Released from Cells under ER Stress}

When the integrity of the ER in tumour cells is disturbed by exposure to an environment lacking oxygen and nutrients, accumulation of misfolded proteins in the ER lumen, an imbalance in calcium homeostasis, and dysregulation of lipid metabolism occur, leading to ER stress [86]. In response to ER stress, an adaptive intracellular signalling pathway, known as the unfolded protein response (UPR), is activated and controls cell fate [87]. The UPR in eukaryotic cells has the following functions: (1) attenuation of protein translation to reduce further translational loads on the ER, (2) the upregulation of molecular chaperone genes involved in protein folding and degradation, and (3) ER-associated degradation clears misfolded proteins by retro-translocating these proteins from the ER lumen into the cytosol through the ubiquitin-proteasome system [88].

There is evidence that control of ER proteostasis via UPR may affect cancer progression [89]. Proteostasis regulated by transmembrane receptor proteins, such as inositol-requiring enzyme (IRE) 1 , activating transcription factor 6, and PERK, is linked to immune responses [90]. ER stress can be 
transferred between cells during the culture of macrophages in conditioned medium from ER-stressed tumour cells with the upregulation of ER stress response genes, such as Grp78, as well as splicing of the mRNA encoding X-box binding protein (XBP) 1, which expands proinflammatory response and activates Wnt signalling [91].

Attenuation of anticancer immune surveillance caused by ER stress might be related to exosomes. Increased exosomal miR-23a-3p levels in ER-stressed hepatocellular carcinoma tissues were correlated with the increased expression of programmed cell death (PD)-ligand 1 (L1) in macrophages, and inversely correlated with patient survival [92]. Severe ER stress in choriocarcinoma cells stimulated the secretion of exosomes carrying DAMP molecules, which might contribute to the inflammatory response [93]. ER stress enhances MVB formation and the release of exosomes, which are related to IRE1- and PERK-mediated pathways [94]. In IRE1 $\alpha$-overexpressed HEK293T cells, the spliced form of XBP1 mRNA was distinctly incorporated into exosomes [95]. Treatment with TEXs increased the expression of ER stress-related genes in normal endothelial cells, disrupted vascular integrity, and promoted tumour metastasis [96].

Overall, as mentioned above, stress and exosomes derived from tumours have effects on different immune or myeloid components (Table 1).

Table 1. Effects of stress and exosomes derived from tumours on different immune or myeloid components.

\begin{tabular}{|c|c|c|}
\hline Stress/Exosome & Immune/Myeloid Component & Effects \\
\hline Oxidative stress or hypoxia & $\begin{array}{l}\text { Tumour-associated macrophage } \\
\text { (TAM) }\end{array}$ & $\begin{array}{l}\text { Infiltration of macrophages, } \\
\text { differentiation of TAM into the M2 } \\
\text { phenotype, protumoral effects }\end{array}$ \\
\hline ER stress & Tumour-associated DC & $\begin{array}{l}\text { XBP1 activation, impairing } \\
\text { antigen-presenting capacity, } \\
\text { cancer progression }\end{array}$ \\
\hline $\begin{array}{l}\text { Exosome isolated from } \\
\text { heat-stressed tumour }\end{array}$ & $\mathrm{DC}, \mathrm{T}$ cell & $\begin{array}{l}\text { Chemoattracting DC and T cell, } \\
\text { antitumour immune response, } \\
\text { inhibiting tumour growth }\end{array}$ \\
\hline $\begin{array}{l}\text { Exosomes derived from hypoxic } \\
\text { cancer }\end{array}$ & Macrophage & $\begin{array}{l}\text { M2-type polarization, } \\
\text { proangiogenic factor expression, } \\
\text { cancer progression }\end{array}$ \\
\hline $\begin{array}{l}\text { TEX in the tumour } \\
\text { microenvironment }\end{array}$ & $\begin{array}{c}\text { Myeloid-derived suppressor cell } \\
\text { (MDSC) }\end{array}$ & $\begin{array}{l}\text { Expansion of MDSC, } \\
\text { immunosuppression }\end{array}$ \\
\hline
\end{tabular}

TAM: tumour-associated macrophage; ER: endoplasmic reticulum; DC: dendritic cell; XBP: X-box binding protein; TEX: tumour-derived exosome; MDSC: myeloid-derived suppressor cell.

\section{Cancer Immunotherapy Based on SG Components or Exosomes for Clinical Application}

Recently, the paradigm of anticancer drug development has shifted to cancer immunotherapy to overcome the limitations of chemotherapy and targeted therapy. Cancer immunotherapy is based primarily on strategies for attacking cancer cells by activating T lymphocytes. Immune checkpoint blockers, including anti-cytotoxic T lymphocyte-associated protein (CTLA)-4 and anti-PD1/PD-L1, have been approved by the U.S. Food and Drug Administration (FDA) and are used for the treatment of melanoma and non-small-cell lung carcinoma (NSCLC) [97].

As exosomes carry informative proteins, RNA, and DNA from the donor cells to the recipient cells, they affect not only the microenvironment around the cells, but also pathophysiological conditions. The unique exosomal cargo that affects the elimination of obsolete proteins and recruitment, differentiation, or polarisation of immune cells has been recognised as an appealing target for novel cancer immunotherapy [98]. Owing to the antigen-presenting characters of DCs and the biocompatibility of exosomes, clinical trials using autologous DC-derived exosomes (DEXs) in metastatic melanoma and NSCLC patients have already been conducted $[99,100]$ (Table 2). It has been suggested that injections 
of DEXs harbouring MHC/tumour peptide complexes would mediate tumour growth retardation with MHC-restricted antigens presenting $\mathrm{CD}^{+}$and $\mathrm{CD}^{+} \mathrm{T}$ cell responses. DEXs isolated from bone marrow- or monocyte-derived DCs possess NKG2D ligands and IL-15R $\alpha$, which trigger the activation and proliferation of NK cells in patients [101]. Cellular stress and tumourigenesis activate pathways for regulating the expression of NKG2D ligands excreted on exosomes, which activate the DDR to repair DNA lesions. To boost NK and CTL responses in NSCLC patients after first-line chemotherapy, exosomes derived from IFN- $\gamma$-matured DCs loaded with MHC-restricted cancer antigens were tested in a recent phase II clinical trial [102].

TEXs enable tumour cells to communicate with and reprogram the recipient stromal cells, immune cells, or bone marrow-derived cells [103]. Despite their delivery of tumour antigens, HSPs, and MHCs, TEXs show somewhat suppressive effects on cancer immunity by inducing apoptosis of CD8 ${ }^{+} \mathrm{T}$ cells, inhibition of monocyte differentiation, suppression of NK cell functions, and the stimulation of regulatory immune cells, such as myeloid-derived suppressor cells (MDSCs) and Treg cells [104]. To potentiate $\mathrm{T}$ cell activation and the antitumour immunity of TEXs, researchers have attempted to isolate TEXs from heat-stressed tumour cells and modify them with superantigens, cytokines, or HSP70 [105-107]. Malignant effusions or autologous ascites from patients were clinically tested as the source for large amounts of exosomes and carcinoembryonic antigens, in combination with the adjuvant GM-CSF, which could beneficially induce the antitumour CTL response without significant toxicities [108]. Mesenchymal stem cell-derived exosomes that show potential in other disease models are also a candidate for cancer immunotherapy [109].

Table 2. Cancer immunotherapy using SG components or exosomes in clinical trials.

\begin{tabular}{|c|c|c|c|c|}
\hline Cancer & $\begin{array}{l}\text { SG Components } \\
\text { or Exosomes }\end{array}$ & $\begin{array}{c}\text { Clinical Trial } \\
\text { Phase }\end{array}$ & Dosage Regimen & Reference \\
\hline $\begin{array}{c}\text { HER2- } \\
\text { negative stage } \\
\text { III-IV breast cancer }\end{array}$ & $\begin{array}{c}\text { CD105/YB-1/SOX2/ } \\
\text { CDH3/MDM2- } \\
\text { polyepitope } \\
\text { plasmid DNA } \\
\text { vaccine with } \\
\text { recombinant } \\
\text { human GM-CSF }\end{array}$ & Phase I & $\begin{array}{l}\text { Every } 28 \text { days } \\
\text { for } 3 \text { months } \\
\text { and booster } \\
\text { vaccines } \\
\text { at } 6 \text { and } 12 \text { months }\end{array}$ & $\begin{array}{c}\text { ClinicalTrials.gov } \\
\text { Identifier: } \\
\text { NCT02157051 } \\
\text { (https: } \\
\text { //clinicaltrials.gov/ } \\
\text { ct2/show/ } \\
\text { NCT02157051) }\end{array}$ \\
\hline $\begin{array}{l}\text { Metastatic } \\
\text { melanoma }\end{array}$ & $\begin{array}{c}\text { Autologous } \\
\text { PBMC-based DEXs } \\
\text { loaded with } \\
\text { MAGEs }\end{array}$ & Phase I & $\begin{array}{l}\text { Four vaccinations } \\
\text { at weekly intervals }\end{array}$ & Escudier et al. [99] \\
\hline Colorectal cancer & $\begin{array}{l}\text { Exosomes derived } \\
\text { from autologous } \\
\text { ascites combined } \\
\text { with GM-CSF }\end{array}$ & Phase I & $\begin{array}{l}\text { Four vaccinations } \\
\text { at weekly intervals }\end{array}$ & Dai et al. [108] \\
\hline Advanced NSCLC & $\begin{array}{l}\text { IFN- } \gamma \text {-matured } \\
\text { DEXs loaded with } \\
\text { MHC-restricted } \\
\text { cancer antigens }\end{array}$ & Phase II & $\begin{array}{l}\text { Four vaccinations } \\
\text { at one-week } \\
\text { intervals after } \\
\text { cyclophosphamide, } \\
\text { followed by six } \\
\text { vaccinations at } \\
\text { two-week intervals }\end{array}$ & Besse et al. [102] \\
\hline
\end{tabular}

SG: stress granule; HER2: human epidermal growth factor receptor 2; YB: Y-box binding protein; GM-CSF: granulocyte-macrophage colony-stimulating factor; PBMC: peripheral blood mononuclear cell; DEX: dendritic cell-derived exosome; MAGE: melanoma-associated antigen; NSCLC: non-small-cell lung carcinoma; IFN: interferon; MHC: major histocompatibility complex. 
To enhance the efficacy of exosome-based therapeutics, researchers have tried adding or combining exosomal contents and other functional ingredients together [110]. Exosomes engineered with the variant of signal regulatory protein $\alpha(\operatorname{SIRP} \alpha)$ antagonise the interaction between CD47 and tumour cells and between SIRP $\alpha$ and macrophages, and increase tumour phagocytosis. Treatment of tumour-bearing mice with exosomes harbouring SIRP $\alpha$ variants have led to intensive infiltration of CD8 ${ }^{+} \mathrm{T}$ cells in the tumour microenvironment, as well as subsequent inhibition of tumour growth [111]. Exosomes derived from hyaluronidase-anchored HEK293T cells, in combination with PD-L1 blocker, exhibited the stimulation of DCs and an antitumour $C D 8^{+} \mathrm{T}$ cell response in mice [112].

Meanwhile, SG formation in tumour cells under stress conditions favours tumour cell survival and confers resistance to anticancer drugs. In some cases, solid tumours may show resistance to Bortezomib, a proteasome inhibitor for the treatment of mantle cell myeloma and multiple myeloma, which is thought to be related to the activation of the stress response [113]. There is an important relationship between selective mRNA translation, stress adaptation, SGs, and tumour progression. Blocking expression of SG-specific proteins, such as YB-1 and G3BP1, significantly reduces tumour progression and metastasis. Intracellular microtubules transport SGs carrying immune checkpoint mRNA to regulate mRNA translation, and T lymphocytes rapidly increase PD1 mRNA expression as soon as $\mathrm{T}$ cell receptors are activated [114].

\section{Exosomal Expression Linked to Cancer Progression: ONCOGENIC miRNAs (onco-miRs) and Tumour Suppressor miRNAs Together with CT Antigens}

RNA analysis revealed that exosomes contain short, non-coding miRNAs with 19-22 nucleotides, as well as mRNAs [115]. The exosomal miRNA cargo exchanged between cells can play a role in drug resistance and the diagnosis of cancer [116]. The miR-155 upregulated in cancer stem cells or chemoresistant cells was transferred to the sensitive recipient cells by exosomes, which mediated breast cancer chemoresistance [117]. Oncogenic miRNAs (onco-miRs) overexpressed in adenocarcinomas, such as miR-223-5p, miR-223-3p, miR-483-5p, miR-409-3p, miR-196-5p, miR-192-5p, miR-146a-5p, and miR-126-5p, were also identified in exosomes isolated from the serum of adenocarcinoma patients [118].

Moreover, exosomal miRNAs mediate the ECM crosstalk between cancer cells and CAFs, and influence the activation of CAFs [119]. Delivery of miR-155 to the recipient cells by pancreatic, ductal, adenocarcinoma-derived exosomes downregulated the stress-induced p53 target gene, which activated the conversion of normal fibroblasts to CAFs [120]. The miR-1247-3p in hepatocellular carcinoma cell (HCC)-derived exosomes targets $\beta$-1,4-galactosyltransferases III in fibroblasts and activates $\beta 1$-integrin-NF- $\mathrm{KB}$ signalling, leading to liver cancer progression and lung metastasis [121]. Exosomal miR-21 and miR-29a in non-small-cell lung carcinoma (NSCLC) can be bound to TLRs, which mediate the prometastatic inflammatory response [122]. According to another study, pancreatic cancer-secreted exosomes transfer miR-212-3p to DCs and inhibits the expression of the transcription factor for MHC II, resulting in immune tolerance [123]. The suppressed proliferation of the recipient PBMCs or macrophages, as well as stimulated tumour cell proliferation, might be caused by the transfer of miR-125a by TEXs [124].

Additionally, miR-584 enriched in HCC-derived exosomes promotes HCC progress by downregulating TGF- $\beta$-activated kinase 1, which controls the cell death response to environmental stress [125]. In lung adenocarcinoma cells, miR-210 is up-regulated by the tissue inhibitor of metalloproteinases-1 along the PI3K/AKT/HIF-1-dependent pathway, and miR-210-accumulated exosomes promote angiogenesis in vitro and in vivo [126]. Studies on exosomal miRNAs under different stress conditions, however, are quite insufficient to date. Further analysis of exosomal gene expression in tumour cells under stress conditions could aid in the identification of the specific targets for cancer immunotherapy. On the other hand, in more advanced metastatic colon cancer, circulating exosomes rather than tumour tissue are enriched with miR-193a, one of the tumour suppressor miRNAs [127]. The tumour-suppressing miR-200 family released into exosomes negatively regulates zinc finger E-box-binding homeobox 1 protein, which contributes to metastasis [128]. 
Interestingly, several CT antigens are also expressed in exosomes as well as the corresponding tumours. Melanoma-associated antigen (MAGE)-B4 showed higher gene expression in urinary exosomes from bladder cancer patients than that in normal control samples [129]. Testis-specific lactate dehydrogenase C4 was upregulated in serumal exosomes from breast cancer patients [130]. CT antigen SPANXB1 was exclusively expressed in circulating small EVs and promoted the metastasis of triple-negative breast cancer [131]. In other words, expression of $\mathrm{CT}$ antigens correlates with tumour progression, and tumour-expressed CT antigens can be combined with exosomes for antigenic presentation. Support of cell-division cycle processes and suppression of apoptosis signaling cascades, as well as the regulation of transcriptional activity involved in gametogenesis via CT antigens, affects tumour growth and metastasis. Although CT antigens on male germline cells, which do not express MHC molecules, cannot be recognized by T cells, DNA demethylation in tumours allows attack by lymphocytes [132,133]. As immunogenic CT antigens are selectively expressed to tumor tissues and exosomes, they have potential as antigen-specific cancer vaccines or diagnostic markers. Clinical trials using CT antigens, such as MAGE (-A1, A3, A4, and A10) and NY-ESO-1, have been conducted (Table 3).

Table 3. Cancer immunotherapy targeting CT antigens in clinical trials.

\begin{tabular}{|c|c|c|c|}
\hline Cancer & Detailed Description & Clinical Trial Phase & $\begin{array}{c}\text { References } \\
\text { (ClinicalTrials.gov } \\
\text { Identifier) }\end{array}$ \\
\hline Multiple myeloma & $\begin{array}{c}\text { MAGE-A3 and } \\
\text { NY-ESO-1 } \\
\text { (peptide vaccination) } \\
\text { combined with } \\
\text { chemotherapy and auto } \\
\text { transplantation }\end{array}$ & Phase II, Phase III & $\begin{array}{c}\text { NCT00090493 } \\
\text { (https://clinicaltrials.gov/ } \\
\text { ct2/show/NCT00090493) }\end{array}$ \\
\hline Stage III or IV melanoma & $\begin{array}{l}\text { Melanoma antigen } \\
\text { peptides (including } \\
\text { NY-ESO-1b analog and } \\
\text { MAGE-A10) and } \\
\text { Montanide adjuvant }\end{array}$ & Phase I & $\begin{array}{c}\text { NCT00112242 } \\
\text { (https://clinicaltrials.gov/ } \\
\text { ct2/show/NCT00112242) }\end{array}$ \\
\hline Metastatic melanoma & $\begin{array}{c}\text { Autologous DCs } \\
\text { transfected with tumour } \\
\text { antigen (including } \\
\text { MAGE-A3) RNA and } \\
\text { proteasome siRNA }\end{array}$ & Phase I & $\begin{array}{c}\text { NCT00672542 } \\
\text { (https://clinicaltrials.gov/ } \\
\text { ct2/show/NCT00672542) }\end{array}$ \\
\hline $\begin{array}{l}\text { Metastatic melanoma } \\
\text { and renal cell cancer }\end{array}$ & $\begin{array}{l}\text { Chemotherapy followed } \\
\text { by anti-NY-ESO-1 T-cell } \\
\text { receptor gene engineered } \\
\text { lymphocytes }\end{array}$ & Phase II & $\begin{array}{c}\text { NCT00670748 } \\
\text { (https://clinicaltrials.gov/ } \\
\text { ct2/show/NCT00670748) }\end{array}$ \\
\hline Melanoma & $\begin{array}{c}\text { MAGE-A3 } \\
\text { plusGSK2132231A } \\
\text { (antigen-specific cancer } \\
\text { immunotherapy) }\end{array}$ & Phase III(failed) & $\begin{array}{c}\text { NCT00796445 } \\
\text { (https://clinicaltrials.gov/ } \\
\text { ct2/show/NCT00796445) }\end{array}$ \\
\hline $\begin{array}{l}\text { NY-ESO-1- } \\
\text { expressing tumours }\end{array}$ & $\begin{array}{l}\text { CpG 7909/ Montanide in } \\
\text { combination with } \\
\text { NY-ESO-1 peptide or } \\
\text { protein }\end{array}$ & Phase I & $\begin{array}{c}\text { NCT00819806 } \\
\text { (https://clinicaltrials.gov/ } \\
\text { ct2/show/NCT00819806) }\end{array}$ \\
\hline $\begin{array}{c}\text { Melanoma } \\
\text { (expressing NY-ESO-1) }\end{array}$ & $\begin{array}{l}\text { Topical Resiquimod as } \\
\text { an adjuvant for } \\
\text { NY-ESO-1 protein, plus } \\
\text { Montanide vaccination }\end{array}$ & Phase I & $\begin{array}{l}\text { NCT00821652 } \\
\text { (https://clinicaltrials.gov/ } \\
\text { ct2/show/NCT00821652) }\end{array}$ \\
\hline
\end{tabular}


Table 3. Cont.

\begin{tabular}{|c|c|c|c|}
\hline Cancer & Detailed Description & Clinical Trial Phase & $\begin{array}{l}\text { References } \\
\text { (ClinicalTrials.gov } \\
\text { Identifier) }\end{array}$ \\
\hline Melanoma & $\begin{array}{l}\text { NY-ESO-1 protein and } \\
\text { TLR3 agonist adjuvant }\end{array}$ & Phase I, Phase II & $\begin{array}{c}\text { NCT01079741 } \\
\text { (https://clinicaltrials.gov/ } \\
\text { ct2/show/NCT01079741) }\end{array}$ \\
\hline NSCLC & $\begin{array}{l}\text { Chemotherapy and } \\
\text { DEXs } \\
\text { (peptides like MAGEs } \\
\text { and NY-ESO-1 pulsed } \\
\text { onto DC) }\end{array}$ & Phase II & $\begin{array}{c}\text { NCT01159288 } \\
\text { (https://clinicaltrials.gov/ } \\
\text { ct2/show/NCT01159288) }\end{array}$ \\
\hline $\begin{array}{l}\text { Neuroblastoma and } \\
\text { sarcoma }\end{array}$ & $\begin{array}{l}\text { Mature DC pulsed with } \\
\text { peptides derived from } \\
\text { NY-ESO-1, MAGE-A1, } \\
\text { and MAGE-A3, preceded } \\
\text { by chemotherapy }\end{array}$ & Phase I & $\begin{array}{c}\text { NCT01241162 } \\
\text { (https://clinicaltrials.gov/ } \\
\text { ct2/show/NCT01241162) }\end{array}$ \\
\hline $\begin{array}{l}\text { Metastatic cutaneous } \\
\text { melanoma }\end{array}$ & $\begin{array}{l}\text { NY-ESO-1 plus } \\
\text { GSK2241658A } \\
\text { (antigen-specific cancer } \\
\text { immunotherapy) }\end{array}$ & Phase I & $\begin{array}{c}\text { NCT01213472 } \\
\text { (https://clinicaltrials.gov/ } \\
\text { ct2/show/NCT01213472) }\end{array}$ \\
\hline Myeloma & $\begin{array}{c}\text { MAGE-A3 immunization } \\
\text { with adjuvant Hiltonol } \\
\text { plus activated } \\
\text { autologous T cells }\end{array}$ & Phase II & $\begin{array}{c}\text { NCT01245673 } \\
\text { (https://clinicaltrials.gov/ } \\
\text { ct2/show/NCT01245673) }\end{array}$ \\
\hline $\begin{array}{l}\text { Hodgkin's or } \\
\text { non-Hodgkin's } \\
\text { lymphoma }\end{array}$ & $\begin{array}{l}\text { CTL primed against } \\
\text { tumour-associated } \\
\text { antigens, including } \\
\text { MAGE-A4 and } \\
\text { NY-ESO-1 }\end{array}$ & Phase I(ongoing) & $\begin{array}{c}\text { NCT01333046 } \\
\text { (https://clinicaltrials.gov/ } \\
\text { ct2/show/NCT01333046) }\end{array}$ \\
\hline Synovial sarcoma & $\begin{array}{c}\text { Genetically engineered } \\
\text { NY-ESO-1-specific T cells } \\
\text { with chemotherapy }\end{array}$ & Phase I & $\begin{array}{c}\text { NCT01343043 } \\
\text { (https://clinicaltrials.gov/ } \\
\text { ct2/show/NCT01343043) }\end{array}$ \\
\hline Multiple myeloma & $\begin{array}{l}\text { Autologous T cells } \\
\text { expressing high affinity, } \\
\text { TCR-specific for } \\
\text { NY-ESO-1 }\end{array}$ & Phase II & $\begin{array}{c}\text { NCT01352286 } \\
\text { (https://clinicaltrials.gov/ } \\
\text { ct2/show/NCT01352286) }\end{array}$ \\
\hline $\begin{array}{l}\text { Stage IIB-IV resected } \\
\text { melanoma }\end{array}$ & $\begin{array}{l}\text { Recombinant MAGE-A3 } \\
\text { protein combined with } \\
\text { immunological adjuvant } \\
\text { system }\end{array}$ & Early Phase I & $\begin{array}{c}\text { NCT01425749 } \\
\text { (https://clinicaltrials.gov/ } \\
\text { ct2/show/NCT01425749) }\end{array}$ \\
\hline $\begin{array}{c}\text { NY-ESO-1- } \\
\text { expressing solid tumours }\end{array}$ & $\begin{array}{l}\text { CD205-NY-ESO-1 fusion } \\
\text { protein with or without } \\
\text { sirolimus }\end{array}$ & Phase I & $\begin{array}{c}\text { NCT01522820 } \\
\text { (https://clinicaltrials.gov/ } \\
\text { ct2/show/NCT01522820) }\end{array}$ \\
\hline
\end{tabular}

CT: cancer/testis; MAGE: melanoma-associated antigen; DC: dendritic cell; TLR: toll-like receptor; NSCLC: non-small-cell lung carcinoma; DEX: dendritic cell-derived exosome; CTL: cytotoxic T lymphocyte; CD: cluster of differentiation.

\section{Conclusions and Future Perspectives}

As seen from the tumour-host crosstalk and cell-to-cell communication at the primary tumour site and distant sites, a multicentric adaptive therapeutic approach is needed for the efficient treatment of cancer [134]. The careful examination of signalling pathways presents an intertwining network involving the partial recruitment of immune cells at each stage, either to check cancer progression or sometimes to escape cancer progression. Although few cancers share specific proteins in common at 
the beginning, the phenotypic heterogeneity exhibited by different cancer cells and among their own populations clearly makes the current targeting techniques for one specific target doubtful.

Hence, the extension of knowledge regarding exosomal components and crosstalk with immune cells under stress in the tumour microenvironment enables us to pool and select candidates for cancer immunotherapy, with the hope of overcoming the feedback mechanisms involved in immunological evasion for cancer progression. Furthermore, novel therapeutic targets, which show higher expression in both testicular germ cells and cancer cells than expression in other normal tissues, and which are closely associated with the pathogenesis of cancer or cell cycle maintenance, can be explored for their synergistic anticancer effect [135].

Author Contributions: Conceptualization, V.K.K. and S.R.H.; methodology and validation, I.-K.P.; investigation, V.K.K. and S.K.; writing-original draft preparation, V.K.K.; writing-review and editing, S.K. and S.R.H.; visualization, D.H.K.; supervision, Y.B., and Y.-k.L.; funding acquisition, Y.-k.L. and S.R.H. All authors have read and agreed to the published version of the manuscript.

Funding: This research was supported by the National Research Foundation of Korea (NRF) grant, funded by the Ministry of Science and ICT (grant numbers NRF-2019R1F1A1057702).

Acknowledgments: We are grateful to Professor In-San Kim (Korea University-Korea Institute of Science and Technology, Korea) and Professor Takbum Ohn (Chosun University, Korea) for providing advice and vital information on exosome-based cancer immunotherapy and RNA granules. We would like to thank Editage (www.editage.co.kr) for English language editing.

Conflicts of Interest: The authors declare no conflict of interest.

\section{References}

1. Wang, M.; Zhao, J.; Zhang, L.; Wei, F.; Lian, Y.; Wu, Y.; Gong, Z.; Zhang, S.; Zhou, J.; Cao, K.; et al. Role of tumor microenvironment in tumorigenesis. J. Cancer 2017, 8, 761-773. [CrossRef] [PubMed]

2. Sever, R.; Brugge, J.S. Signal transduction in cancer. Cold Spring Harb. Perspect. Med. 2015, 5, a006098. [CrossRef] [PubMed]

3. Simpson, A.J.; Caballero, O.L.; Jungbluth, A.; Chen, Y.-T.; Old, L.J. Cancer/testis antigens, gametogenesis and cancer. Nat. Rev. Cancer 2005, 5, 615-625. [CrossRef] [PubMed]

4. Hanahan, D.; Weinberg, R.A. Hallmarks of cancer: The next generation. Cell 2011, 144, 646-674. [CrossRef]

5. Meseure, D.; Drak Alsibai, K.; Nicolas, A. Pivotal role of pervasive neoplastic and stromal cells reprogramming in circulating tumor cells dissemination and metastatic colonization. Cancer Microenviron. 2014, 7, 95-115. [CrossRef]

6. Anderson, P.; Kedersha, N. RNA granules. J. Cell Biol. 2006, 172, 803-808. [CrossRef]

7. Gao, X.; Jiang, L.; Gong, Y.; Chen, X.; Ying, M.; Zhu, H.; He, Q.; Yang, B.; Cao, J. Stress granule: A promising target for cancer treatment. Br. J. Pharmacol. 2019, 176, 4421-4433. [CrossRef]

8. Manandhar, S.; Park, J.; Kothandan, V.K.; Lee, J.; Alam, F.; Jee, J.-P.; Hwang, J.; Byun, Y.; Hwang, S.R. Properties of Heparinoids Premixed with Tumor-Derived Extracellular Vesicles. Bioconjug. Chem. 2018, 29, 3757-3767. [CrossRef]

9. Suchorska, W.M.; Lach, M.S. The role of exosomes in tumor progression and metastasis (Review). Oncol. Rep. 2016, 35, 1237-1244. [CrossRef]

10. van der Goot, F.G.; Gruenberg, J. Intra-endosomal membrane traffic. Trends Cell Biol. 2006, 16, 514-521. [CrossRef]

11. Ramachandran, S.; Palanisamy, V. Horizontal transfer of RNAs: Exosomes as mediators of intercellular communication. Wiley Interdiscip. Rev. RNA 2012, 3, 286-293. [CrossRef] [PubMed]

12. Peng, P.; Yan, Y.; Keng, S. Exosomes in the ascites of ovarian cancer patients: Origin and effects on anti-tumor immunity. Oncol. Rep. 2011, 25, 749-762. [CrossRef] [PubMed]

13. Andre, F.; Schartz, N.E.; Movassagh, M.; Flament, C.; Pautier, P.; Morice, P.; Pomel, C.; Lhomme, C.; Escudier, B.; Le Chevalier, T.; et al. Malignant effusions and immunogenic tumour-derived exosomes. Lancet 2002, 360, 295-305. [CrossRef]

14. Taylor, D.D.; Gercel-Taylor, C. Exosomes/microvesicles: Mediators of cancer-associated immunosuppressive microenvironments. Semin. Immunopathol. 2011, 33, 441-454. [CrossRef] [PubMed] 
15. Corrado, C.; Raimondo, S.; Chiesi, A.; Ciccia, F.; De Leo, G.; Alessandro, R. Exosomes as intercellular signaling organelles involved in health and disease: Basic science and clinical applications. Int. J. Mol. Sci. 2013, 14, 5338-5366. [CrossRef]

16. Kucharzewska, P.; Belting, M. Emerging roles of extracellular vesicles in the adaptive response of tumour cells to microenvironmental stress. J. Extracell. Vesicles 2013, 2. [CrossRef]

17. Azmi, A.S.; Bao, B.; Sarkar, F.H. Exosomes in cancer development, metastasis, and drug resistance: A comprehensive review. Cancer Metastasis Rev. 2013, 32, 623-642. [CrossRef]

18. Shao, C.; Yang, F.; Miao, S.; Liu, W.; Wang, C.; Shu, Y.; Shen, H. Role of hypoxia-induced exosomes in tumor biology. Mol. Cancer 2018, 17, 120. [CrossRef]

19. Taraboletti, G.; D’Ascenzo, S.; Giusti, I.; Marchetti, D.; Borsotti, P.; Millimaggi, D.; Giavazzi, R.; Pavan, A.; Dolo, V. Bioavailability of VEGF in tumor-shed vesicles depends on vesicle burst induced by acidic $\mathrm{pH}$. Neoplasia 2006, 8, 96-103. [CrossRef]

20. Eldh, M.; Ekstrom, K.; Valadi, H.; Sjostrand, M.; Olsson, B.; Jernas, M.; Lotvall, J. Exosomes communicate protective messages during oxidative stress; possible role of exosomal shuttle RNA. PLoS ONE 2010, 5, e15353. [CrossRef]

21. Mincheva-Nilsson, L.; Baranov, V. Cancer exosomes and NKG2D receptor-ligand interactions: Impairing NKG2D-mediated cytotoxicity and anti-tumour immune surveillance. Semin. Cancer Biol. 2014, 28, 24-30. [CrossRef]

22. Jabbari, N.; Karimipour, M.; Khaksar, M.; Akbariazar, E.; Heidarzadeh, M.; Mojarad, B.; Aftab, H.; Rahbarghazi, R.; Rezaie, J. Tumor-derived extracellular vesicles: Insights into bystander effects of exosomes after irradiation. Lasers Med. Sci. 2019, 1-15. [CrossRef]

23. Iannello, A.; Raulet, D.H. Immunosurveillance of senescent cancer cells by natural killer cells. Oncoimmunology 2014, 3, e27616. [CrossRef] [PubMed]

24. Krysko, D.V.; Garg, A.D.; Kaczmarek, A.; Krysko, O.; Agostinis, P.; Vandenabeele, P. Immunogenic cell death and DAMPs in cancer therapy. Nat. Rev. Cancer 2012, 12, 860-875. [CrossRef]

25. Garg, A.D.; Galluzzi, L.; Apetoh, L.; Baert, T.; Birge, R.B.; Bravo-San Pedro, J.M.; Breckpot, K.; Brough, D.; Chaurio, R.; Cirone, M.; et al. Molecular and Translational Classifications of DAMPs in Immunogenic Cell Death. Front. Immunol. 2015, 6, 588. [CrossRef]

26. Land, W.G.; Agostinis, P.; Gasser, S.; Garg, A.D.; Linkermann, A. DAMP-Induced Allograft and Tumor Rejection: The Circle Is Closing. Am. J. Transplant. 2016, 16, 3322-3337. [CrossRef]

27. Takeuchi, O.; Akira, S. Pattern recognition receptors and inflammation. Cell 2010, 140, 805-820. [CrossRef]

28. Scanlan, M.J.; Gure, A.O.; Jungbluth, A.A.; Old, L.J.; Chen, Y.T. Cancer/testis antigens: An expanding family of targets for cancer immunotherapy. Immunol. Rev. 2002, 188, 22-32. [CrossRef] [PubMed]

29. Anderson, P.; Kedersha, N.; Ivanov, P. Stress granules, P-bodies and cancer. Biochim. Biophys. Acta 2015, 1849, 861-870. [CrossRef] [PubMed]

30. Reineke, L.C.; Dougherty, J.D.; Pierre, P.; Lloyd, R.E. Large G3BP-induced granules trigger eIF2alpha phosphorylation. Mol. Biol. Cell 2012, 23, 3499-3510. [CrossRef] [PubMed]

31. Ackerman, D.; Simon, M.C. Hypoxia, lipids, and cancer: Surviving the harsh tumor microenvironment. Trends Cell Biol. 2014, 24, 472-478. [CrossRef] [PubMed]

32. Pouysségur, J.; Dayan, F.; Mazure, N.M. Hypoxia signalling in cancer and approaches to enforce tumour regression. Nature 2006, 441, 437-443. [CrossRef] [PubMed]

33. Cubillos-Ruiz, J.R.; Bettigole, S.E.; Glimcher, L.H. Tumorigenic and immunosuppressive effects of endoplasmic reticulum stress in cancer. Cell 2017, 168, 692-706. [CrossRef] [PubMed]

34. McInerney, G.M.; Kedersha, N.L.; Kaufman, R.J.; Anderson, P.; Liljestrom, P. Importance of eIF2alpha phosphorylation and stress granule assembly in alphavirus translation regulation. Mol. Biol. Cell 2005, 16, 3753-3763. [CrossRef] [PubMed]

35. Kedersha, N.; Stoecklin, G.; Ayodele, M.; Yacono, P.; Lykke-Andersen, J.; Fritzler, M.J.; Scheuner, D.; Kaufman, R.J.; Golan, D.E.; Anderson, P. Stress granules and processing bodies are dynamically linked sites of mRNP remodeling. J. Cell Biol. 2005, 169, 871-884. [CrossRef]

36. Kedersha, N.; Ivanov, P.; Anderson, P. Stress granules and cell signaling: More than just a passing phase? Trends Biochem. Sci. 2013, 38, 494-506. [CrossRef]

37. Gilks, N.; Kedersha, N.; Ayodele, M.; Shen, L.; Stoecklin, G.; Dember, L.M.; Anderson, P. Stress granule assembly is mediated by prion-like aggregation of TIA-1. Mol. Biol. Cell 2004, 15, 5383-5398. [CrossRef] 
38. Tourrière,H.; Chebli, K.; Zekri, L.; Courselaud, B.; Blanchard, J.M.; Bertrand, E.; Tazi, J. The RasGAP-associated endoribonuclease G3BP assembles stress granules. J. Cell Biol. 2003, 160, 823-831. [CrossRef]

39. Bley, N.; Lederer, M.; Pfalz, B.; Reinke, C.; Fuchs, T.; Glass, M.; Moller, B.; Huttelmaier, S. Stress granules are dispensable for mRNA stabilization during cellular stress. Nucleic Acids Res. 2015, 43, e26. [CrossRef]

40. Kedersha, N.; Cho, M.R.; Li, W.; Yacono, P.W.; Chen, S.; Gilks, N.; Golan, D.E.; Anderson, P. Dynamic shuttling of TIA-1 accompanies the recruitment of mRNA to mammalian stress granules. J. Cell Biol. 2000, 151, 1257-1268. [CrossRef]

41. Mollet, S.; Cougot, N.; Wilczynska, A.; Dautry, F.; Kress, M.; Bertrand, E.; Weil, D. Translationally repressed mRNA transiently cycles through stress granules during stress. Mol. Biol. Cell 2008, 19, 4469-4479. [CrossRef] [PubMed]

42. Yoon, S.P.; Kim, H.H.; Kim, J.; Park, R.Y.; Ohn, T. Regulation of cellular RNA nano-particle assembly by splicing factor SRp20. J. Nanosci. Nanotechnol. 2013, 13, 184-187. [CrossRef] [PubMed]

43. Somasekharan, S.P.; El-Naggar, A.; Leprivier, G.; Cheng, H.; Hajee, S.; Grunewald, T.G.; Zhang, F.; Ng, T.; Delattre, O.; Evdokimova, V. YB-1 regulates stress granule formation and tumor progression by translationally activating G3BP1. J. Cell Biol. 2015, 208, 913-929. [CrossRef] [PubMed]

44. Takahashi, M.; Shimajiri, S.; Izumi, H.; Hirano, G.; Kashiwagi, E.; Yasuniwa, Y.; Wu, Y.; Han, B.; Akiyama, M.; Nishizawa, S. Y-box binding protein-1 is a novel molecular target for tumor vessels. Cancer Sci. 2010, 101, 1367-1373. [CrossRef] [PubMed]

45. Hsieh, A.C.; Liu, Y.; Edlind, M.P.; Ingolia, N.T.; Janes, M.R.; Sher, A.; Shi, E.Y.; Stumpf, C.R.; Christensen, C.; Bonham, M.J. The translational landscape of mTOR signalling steers cancer initiation and metastasis. Nature 2012, 485, 55-61. [CrossRef] [PubMed]

46. Evdokimova, V.; Tognon, C.; Ng, T.; Ruzanov, P.; Melnyk, N.; Fink, D.; Sorokin, A.; Ovchinnikov, L.P.; Davicioni, E.; Triche, T.J.; et al. Translational activation of snail1 and other developmentally regulated transcription factors by YB-1 promotes an epithelial-mesenchymal transition. Cancer Cell 2009, 15, 402-415. [CrossRef]

47. Lovett, D.H.; Cheng, S.; Cape, L.; Pollock, A.S.; Mertens, P.R. YB-1 alters MT1-MMP trafficking and stimulates MCF-7 breast tumor invasion and metastasis. Biochem. Biophys. Res. Commun. 2010, 398, 482-488. [CrossRef]

48. Wu, Y.; Yamada, S.; Izumi, H.; Li, Z.; Shimajiri, S.; Wang, K.Y.; Liu, Y.P.; Kohno, K.; Sasaguri, Y. Strong $\mathrm{YB}-1$ expression is associated with liver metastasis progression and predicts shorter disease-free survival in advanced gastric cancer. J. Surg. Oncol. 2012, 105, 724-730. [CrossRef]

49. Ohga, T.; Uchiumi, T.; Makino, Y.; Koike, K.; Wada, M.; Kuwano, M.; Kohno, K. Direct involvement of the Y-box binding protein $\mathrm{YB}-1$ in genotoxic stress-induced activation of the human multidrug resistance 1 gene. J. Biol. Chem. 1998, 273, 5997-6000. [CrossRef]

50. Matsumoto, S.; Uchiumi, T.; Tanamachi, H.; Saito, T.; Yagi, M.; Takazaki, S.; Kanki, T.; Kang, D. Ribonucleoprotein Y-box-binding protein-1 regulates mitochondrial oxidative phosphorylation (OXPHOS) protein expression after serum stimulation through binding to OXPHOS mRNA. Biochem. J. 2012, 443, 573-584. [CrossRef]

51. Eliseeva, I.A.; Kim, E.R.; Guryanov, S.G.; Ovchinnikov, L.P.; Lyabin, D.N. Y-box-binding protein 1 (YB-1) and its functions. Biochemistry 2011, 76, 1402-1433. [CrossRef] [PubMed]

52. Rauen, T.; Raffetseder, U.; Frye, B.C.; Djudjaj, S.; Mühlenberg, P.J.; Eitner, F.; Lendahl, U.; Bernhagen, J.; Dooley, S.; Mertens, P.R. YB-1 acts as a ligand for Notch-3 receptors and modulates receptor activation. J. Biol. Chem. 2009, 284, 26928-26940. [CrossRef] [PubMed]

53. Kossinova, O.A.; Gopanenko, A.V.; Tamkovich, S.N.; Krasheninina, O.A.; Tupikin, A.E.; Kiseleva, E.; Yanshina, D.D.; Malygin, A.A.; Ven'yaminova, A.G.; Kabilov, M.R. Cytosolic YB-1 and NSUN2 are the only proteins recognizing specific motifs present in mRNAs enriched in exosomes. Biochim. Biophys. Acta Proteins Proteom. 2017, 1865, 664-673. [CrossRef]

54. Kang, S.; Lee, T.A.; Ra, E.A.; Lee, E.; Jin Choi, H.; Lee, S.; Park, B. Differential control of interleukin-6 mRNA levels by cellular distribution of YB-1. PLoS ONE 2014, 9. [CrossRef] [PubMed]

55. Lindquist, J.A.; Mertens, P.R. Cold shock proteins: From cellular mechanisms to pathophysiology and disease. Cell Commun. Signal. 2018, 16, 63. [CrossRef] [PubMed]

56. Sorokin, A.V.; Selyutina, A.A.; Skabkin, M.A.; Guryanov, S.G.; Nazimov, I.V.; Richard, C.; Th’Ng, J.; Yau, J.; Sorensen, P.H.; Ovchinnikov, L.P. Proteasome-mediated cleavage of the Y-box-binding protein 1 is linked to DNA-damage stress response. EMBO J. 2005, 24, 3602-3612. [CrossRef] 
57. Frydrychowicz, M.; Kolecka-Bednarczyk, A.; Madejczyk, M.; Yasar, S.; Dworacki, G. Exosomes-structure, biogenesis and biological role in non-small-cell lung cancer. Scand. J. Immunol. 2015, 81, 2-10. [CrossRef]

58. Villarroya-Beltri, C.; Baixauli, F.; Gutierrez-Vazquez, C.; Sanchez-Madrid, F.; Mittelbrunn, M. Sorting it out: Regulation of exosome loading. Semin. Cancer Biol. 2014, 28, 3-13. [CrossRef]

59. Evans, S.S.; Repasky, E.A.; Fisher, D.T. Fever and the thermal regulation of immunity: The immune system feels the heat. Nat. Rev. Immunol. 2015, 15, 335-349. [CrossRef]

60. Chen, T.; Guo, J.; Yang, M.; Zhu, X.; Cao, X. Chemokine-containing exosomes are released from heat-stressed tumor cells via lipid raft-dependent pathway and act as efficient tumor vaccine. J. Immunol. 2011, 186, 2219-2228. [CrossRef]

61. Bianco, F.; Pravettoni, E.; Colombo, A.; Schenk, U.; Möller, T.; Matteoli, M.; Verderio, C. Astrocyte-derived ATP induces vesicle shedding and IL-1 $\beta$ release from microglia. J. Immunol. 2005, 174, 7268-7277. [CrossRef] [PubMed]

62. Savina, A.; Furlán, M.; Vidal, M.; Colombo, M.I. Exosome release is regulated by a calcium-dependent mechanism in K562 cells. J. Biol. Chem. 2003, 278, 20083-20090. [CrossRef]

63. Kunigelis, K.E.; Graner, M.W. The dichotomy of tumor exosomes (TEX) in cancer immunity: Is it all in the ConTEXt? Vaccines 2015, 3, 1019-1051. [CrossRef] [PubMed]

64. Zhong, H.; Yang, Y.; Ma, S.; Xiu, F.; Cai, Z.; Zhao, H.; Du, L. Induction of a tumour-specific CTL response by exosomes isolated from heat-treated malignant ascites of gastric cancer patients. Int. J. Hyperth. 2011, 27, 604-611. [CrossRef] [PubMed]

65. Dai, S.; Wan, T.; Wang, B.; Zhou, X.; Xiu, F.; Chen, T.; Wu, Y.; Cao, X. More efficient induction of HLA-A* 0201-restricted and carcinoembryonic antigen (CEA)-specific CTL response by immunization with exosomes prepared from heat-stressed CEA-positive tumor cells. Clin. Cancer Res. 2005, 11, 7554-7563. [CrossRef] [PubMed]

66. Murshid, A.; Gong, J.; Calderwood, S.K. The role of heat shock proteins in antigen cross presentation. Front. Immunol. 2012, 3, 63. [CrossRef]

67. Lancaster, G.I.; Febbraio, M.A. Exosome-dependent trafficking of HSP70: A novel secretory pathway for cellular stress proteins. J. Biol. Chem. 2005, 280, 23349-23355. [CrossRef]

68. Halliwell, B. Oxidative stress and cancer: Have we moved forward? Biochem. J. 2007, 401, 1-11. [CrossRef]

69. Gilkes, D.M.; Semenza, G.L.; Wirtz, D. Hypoxia and the extracellular matrix: Drivers of tumour metastasis. Nat. Rev. Cancer 2014, 14, 430-439. [CrossRef]

70. Zhang, H.; Bosch-Marce, M.; Shimoda, L.A.; Tan, Y.S.; Baek, J.H.; Wesley, J.B.; Gonzalez, F.J.; Semenza, G.L. Mitochondrial autophagy is an HIF-1-dependent adaptive metabolic response to hypoxia. J. Biol. Chem. 2008, 283, 10892-10903. [CrossRef] [PubMed]

71. Martinez-Outschoorn, U.E.; Trimmer, C.; Lin, Z.; Whitaker-Menezes, D.; Chiavarina, B.; Zhou, J.; Wang, C.; Pavlides, S.; Martinez-Cantarin, M.P.; Capozza, F.; et al. Autophagy in cancer associated fibroblasts promotes tumor cell survival: Role of hypoxia, HIF1 induction and NFkappaB activation in the tumor stromal microenvironment. Cell Cycle 2010, 9, 3515-3533. [CrossRef] [PubMed]

72. Menard, J.A.; Cerezo-Magana, M.; Belting, M. Functional role of extracellular vesicles and lipoproteins in the tumour microenvironment. Philos. Trans. R. Soc. B Biol. Sci. 2018, 373. [CrossRef] [PubMed]

73. Meng, W.; Hao, Y.; He, C.; Li, L.; Zhu, G. Exosome-orchestrated hypoxic tumor microenvironment. Mol. Cancer 2019, 18, 57. [CrossRef] [PubMed]

74. Zhang, X.; Yuan, X.; Shi, H.; Wu, L.; Qian, H.; Xu, W. Exosomes in cancer: Small particle, big player. J. Hematol. Oncol. 2015, 8, 83. [CrossRef] [PubMed]

75. Choudhry, H.; Harris, A.L. Advances in Hypoxia-Inducible Factor Biology. Cell Metab. 2018, 27, $281-298$. [CrossRef] [PubMed]

76. Sun, Z.; Shi, K.; Yang, S.; Liu, J.; Zhou, Q.; Wang, G.; Song, J.; Li, Z.; Zhang, Z.; Yuan, W. Effect of exosomal miRNA on cancer biology and clinical applications. Mol. Cancer 2018, 17, 147. [CrossRef]

77. Wang, X.; Luo, G.; Zhang, K.; Cao, J.; Huang, C.; Jiang, T.; Liu, B.; Su, L.; Qiu, Z. Hypoxic tumor-derived exosomal miR-301a mediates M2 macrophage polarization via PTEN/PI3K $\gamma$ to promote pancreatic cancer metastasis. Cancer Res. 2018, 78, 4586-4598. [CrossRef]

78. Li, Z.; He, F.; Yang, Z.; Cao, X.; Dai, S.; Zou, J.; Xu, P.; Zhou, Z. Exosomal miR-25-3p derived from hypoxia tumor mediates IL-6 secretion and stimulates cell viability and migration in breast cancer. RSC Adv. 2019, 9, 1451-1459. [CrossRef] 
79. You, N.; Liu, W.; Tang, L.; Zhong, X.; Ji, R.; Zhang, N.; Wang, D.; He, Y.; Dou, K.; Tao, K. Tg737 signaling is required for hypoxia-enhanced invasion and migration of hepatoma cells. J. Exp. Clin. Cancer Res. 2012, 31, 75. [CrossRef]

80. Park, J.E.; Tan, H.S.; Datta, A.; Lai, R.C.; Zhang, H.; Meng, W.; Lim, S.K.; Sze, S.K. Hypoxic tumor cell modulates its microenvironment to enhance angiogenic and metastatic potential by secretion of proteins and exosomes. Mol. Cell. Proteom. 2010, 9, 1085-1099. [CrossRef]

81. Kore, R.A.; Edmondson, J.L.; Jenkins, S.V.; Jamshidi-Parsian, A.; Dings, R.P.; Reyna, N.S.; Griffin, R.J. Hypoxia-derived exosomes induce putative altered pathways in biosynthesis and ion regulatory channels in glioblastoma cells. Biochem. Biophys. Rep. 2018, 14, 104-113. [CrossRef] [PubMed]

82. Baginska, J.; Viry, E.; Paggetti, J.; Medves, S.; Berchem, G.; Moussay, E.; Janji, B. The critical role of the tumor microenvironment in shaping natural killer cell-mediated anti-tumor immunity. Front. Immunol. 2013, 4, 490. [CrossRef] [PubMed]

83. Clayton, A.; Tabi, Z. Exosomes and the MICA-NKG2D system in cancer. Blood Cells Mol. Dis. 2005, 34, 206-213. [CrossRef] [PubMed]

84. Vitale, M.; Cantoni, C.; Pietra, G.; Mingari, M.C.; Moretta, L. Effect of tumor cells and tumor microenvironment on NK-cell function. Eur. J. Immunol. 2014, 44, 1582-1592. [CrossRef] [PubMed]

85. Park, J.E.; Dutta, B.; Tse, S.W.; Gupta, N.; Tan, C.F.; Low, J.K.; Yeoh, K.W.; Kon, O.L.; Tam, J.P.; Sze, S.K. Hypoxia-induced tumor exosomes promote M2-like macrophage polarization of infiltrating myeloid cells and microRNA-mediated metabolic shift. Oncogene 2019, 38, 5158-5173. [CrossRef] [PubMed]

86. Kato, H.; Nishitoh, H. Stress responses from the endoplasmic reticulum in cancer. Front. Oncol. $2015,5,93$. [CrossRef] [PubMed]

87. Hetz, C.; Papa, F.R. The Unfolded Protein Response and Cell Fate Control. Mol. Cell 2018, 69, $169-181$. [CrossRef] [PubMed]

88. Ron, D.; Walter, P. Signal integration in the endoplasmic reticulum unfolded protein response. Nat. Rev. Mol. Cell Biol. 2007, 8, 519-529. [CrossRef] [PubMed]

89. Urra, H.; Dufey, E.; Avril, T.; Chevet, E.; Hetz, C. Endoplasmic Reticulum Stress and the Hallmarks of Cancer. Trends Cancer 2016, 2, 252-262. [CrossRef]

90. Miles, J.; Scherz-Shouval, R.; van Oosten-Hawle, P. Expanding the Organismal Proteostasis Network: Linking Systemic Stress Signaling with the Innate Immune Response. Trends Biochem. Sci. 2019, 44, 927-942. [CrossRef]

91. Mahadevan, N.R.; Rodvold, J.; Sepulveda, H.; Rossi, S.; Drew, A.F.; Zanetti, M. Transmission of endoplasmic reticulum stress and pro-inflammation from tumor cells to myeloid cells. Proc. Natl. Acad. Sci. USA 2011, 108, 6561-6566. [CrossRef] [PubMed]

92. Liu, J.; Fan, L.; Yu, H.; Zhang, J.; He, Y.; Feng, D.; Wang, F.; Li, X.; Liu, Q.; Li, Y. Endoplasmic Reticulum Stress Causes Liver Cancer Cells to Release Exosomal miR-23a-3p and Up-regulate Programmed Death Ligand 1 Expression in Macrophages. Hepatology 2019, 70, 241-258. [CrossRef] [PubMed]

93. Collett, G.P.; Redman, C.W.; Sargent, I.L.; Vatish, M. Endoplasmic reticulum stress stimulates the release of extracellular vesicles carrying danger-associated molecular pattern (DAMP) molecules. Oncotarget 2018, 9, 6707-6717. [CrossRef] [PubMed]

94. Kanemoto, S.; Nitani, R.; Murakami, T.; Kaneko, M.; Asada, R.; Matsuhisa, K.; Saito, A.; Imaizumi, K. Multivesicular body formation enhancement and exosome release during endoplasmic reticulum stress. Biochem. Biophys. Res. Commun. 2016, 480, 166-172. [CrossRef]

95. Hosoi, T.; Nakashima, M.; Ozawa, K. Incorporation of the Endoplasmic Reticulum Stress-Induced Spliced Form of XBP1 mRNA in the Exosomes. Front. Physiol. 2018, 9, 1357. [CrossRef]

96. Lin, Y.; Zhang, C.; Xiang, P.; Shen, J.; Sun, W.; Yu, H. Exosomes derived from HeLa cells break down vascular integrity by triggering endoplasmic reticulum stress in endothelial cells. J. Extracell. Vesicles 2020, 9, 1722385. [CrossRef]

97. Topalian, S.L.; Drake, C.G.; Pardoll, D.M. Immune checkpoint blockade: A common denominator approach to cancer therapy. Cancer Cell 2015, 27, 450-461. [CrossRef]

98. Mignot, G.; Roux, S.; Thery, C.; Segura, E.; Zitvogel, L. Prospects for exosomes in immunotherapy of cancer. J. Cell. Mol. Med. 2006, 10, 376-388. [CrossRef] 
99. Escudier, B.; Dorval, T.; Chaput, N.; Andre, F.; Caby, M.P.; Novault, S.; Flament, C.; Leboulaire, C.; Borg, C.; Amigorena, S.; et al. Vaccination of metastatic melanoma patients with autologous dendritic cell (DC) derived-exosomes: Results of thefirst phase I clinical trial. J. Transl. Med. 2005, 3, 10. [CrossRef]

100. Morse, M.A.; Garst, J.; Osada, T.; Khan, S.; Hobeika, A.; Clay, T.M.; Valente, N.; Shreeniwas, R.; Sutton, M.A.; Delcayre, A.; et al. A phase I study of dexosome immunotherapy in patients with advanced non-small cell lung cancer. J. Transl. Med. 2005, 3, 9. [CrossRef]

101. Viaud, S.; Terme, M.; Flament, C.; Taieb, J.; Andre, F.; Novault, S.; Escudier, B.; Robert, C.; Caillat-Zucman, S.; Tursz, T. Dendritic cell-derived exosomes promote natural killer cell activation and proliferation: A role for NKG2D ligands and IL-15R $\alpha$. PLoS ONE 2009, 4. [CrossRef] [PubMed]

102. Besse, B.; Charrier, M.; Lapierre, V.; Dansin, E.; Lantz, O.; Planchard, D.; Le Chevalier, T.; Livartoski, A.; Barlesi, F.; Laplanche, A. Dendritic cell-derived exosomes as maintenance immunotherapy after first line chemotherapy in NSCLC. Oncoimmunology 2016, 5, e1071008. [CrossRef] [PubMed]

103. Becker, A.; Thakur, B.K.; Weiss, J.M.; Kim, H.S.; Peinado, H.; Lyden, D. Extracellular Vesicles in Cancer: Cell-to-Cell Mediators of Metastasis. Cancer Cell 2016, 30, 836-848. [CrossRef]

104. Whiteside, T.L. The effect of tumor-derived exosomes on immune regulation and cancer immunotherapy. Future Oncol. 2017, 13, 2583-2592. [CrossRef] [PubMed]

105. Dai, S.; Zhou, X.; Wang, B.; Wang, Q.; Fu, Y.; Chen, T.; Wan, T.; Yu, Y.; Cao, X. Enhanced induction of dendritic cell maturation and HLA-A*0201-restricted CEA-specific CD8(+) CTL response by exosomes derived from IL-18 gene-modified CEA-positive tumor cells. J. Mol. Med. 2006, 84, 1067-1076. [CrossRef]

106. Xiu, F.; Cai, Z.; Yang, Y.; Wang, X.; Wang, J.; Cao, X. Correction to: Surface anchorage of superantigen SEA promotes induction of specific antitumor immune response by tumor-derived exosomes. J. Mol. Med. 2020, 98, 323-324. [CrossRef]

107. Xie, Y.; Bai, O.; Zhang, H.; Yuan, J.; Zong, S.; Chibbar, R.; Slattery, K.; Qureshi, M.; Wei, Y.; Deng, Y. Membrane-bound HSP70-engineered myeloma cell-derived exosomes stimulate more efficient CD8+CTL-and NK-mediated antitumour immunity than exosomes released from heat-shocked tumour cells expressing cytoplasmic HSP70. J. Cell. Mol. Med. 2010, 14, 2655-2666. [CrossRef]

108. Dai, S.; Wei, D.; Wu, Z.; Zhou, X.; Wei, X.; Huang, H.; Li, G. Phase I clinical trial of autologous ascites-derived exosomes combined with GM-CSF for colorectal cancer. Mol. Ther. 2008, 16, 782-790. [CrossRef]

109. Giebel, B.; Kordelas, L.; Borger, V. Clinical potential of mesenchymal stem/stromal cell-derived extracellular vesicles. Stem Cell Investig. 2017, 4. [CrossRef]

110. Bell, B.M.; Kirk, I.D.; Hiltbrunner, S.; Gabrielsson, S.; Bultema, J.J. Designer exosomes as next-generation cancer immunotherapy. Nanomedicine 2016, 12, 163-169. [CrossRef]

111. Koh, E.; Lee, E.J.; Nam, G.H.; Hong, Y.; Cho, E.; Yang, Y.; Kim, I.S. Exosome-SIRPalpha, a CD47 blockade increases cancer cell phagocytosis. Biomaterials 2017, 121, 121-129. [CrossRef] [PubMed]

112. Hong, Y.; Kim, Y.K.; Kim, G.B.; Nam, G.-H.; Kim, S.A.; Park, Y.; Yang, Y.; Kim, I.-S. Degradation of tumour stromal hyaluronan by small extracellular vesicle-PH20 stimulates CD103+ dendritic cells and in combination with PD-L1 blockade boosts anti-tumour immunity. J. Extracell. Vesicles 2019, 8, 1670893. [CrossRef] [PubMed]

113. Fournier, M.J.; Gareau, C.; Mazroui, R. The chemotherapeutic agent bortezomib induces the formation of stress granules. Cancer Cell Int. 2010, 10, 12. [CrossRef]

114. Franchini, D.M.; Lanvin, O.; Tosolini, M.; Patras de Campaigno, E.; Cammas, A.; Pericart, S.; Scarlata, C.M.; Lebras, M.; Rossi, C.; Ligat, L.; et al. Microtubule-Driven Stress Granule Dynamics Regulate Inhibitory Immune Checkpoint Expression in T Cells. Cell Rep. 2019, 26, 94-107. [CrossRef] [PubMed]

115. Valadi, H.; Ekström, K.; Bossios, A.; Sjöstrand, M.; Lee, J.J.; Lötvall, J.O. Exosome-mediated transfer of mRNAs and microRNAs is a novel mechanism of genetic exchange between cells. Nat. Cell Biol. 2007, 9, 654-659. [CrossRef] [PubMed]

116. Zhao, L.; Liu, W.; Xiao, J.; Cao, B. The role of exosomes and "exosomal shuttle microRNA" in tumorigenesis and drug resistance. Cancer Lett. 2015, 356, 339-346. [CrossRef]

117. Santos, J.C.; Lima, N.D.S.; Sarian, L.O.; Matheu, A.; Ribeiro, M.L.; Derchain, S.F.M. Exosome-mediated breast cancer chemoresistance via miR-155 transfer. Sci. Rep. 2018, 8, 1-11. [CrossRef] [PubMed]

118. Warnecke-Eberz, U.; Chon, S.H.; Holscher, A.H.; Drebber, U.; Bollschweiler, E. Exosomal onco-miRs from serum of patients with adenocarcinoma of the esophagus: Comparison of miRNA profiles of exosomes and matching tumor. Tumor Biol. 2015, 36, 4643-4653. [CrossRef] 
119. Yang, F.; Ning, Z.; Ma, L.; Liu, W.; Shao, C.; Shu, Y.; Shen, H. Exosomal miRNAs and miRNA dysregulation in cancer-associated fibroblasts. Mol. Cancer 2017, 16, 148. [CrossRef]

120. Pang, W.; Su, J.; Wang, Y.; Feng, H.; Dai, X.; Yuan, Y.; Chen, X.; Yao, W. Pancreatic cancer-secreted miR-155 implicates in the conversion from normal fibroblasts to cancer-associated fibroblasts. Cancer Sci. 2015, 106, 1362-1369. [CrossRef]

121. Fang, T.; Lv, H.; Lv, G.; Li, T.; Wang, C.; Han, Q.; Yu, L.; Su, B.; Guo, L.; Huang, S.; et al. Tumor-derived exosomal miR-1247-3p induces cancer-associated fibroblast activation to foster lung metastasis of liver cancer. Nat. Commun. 2018, 9, 1-13. [CrossRef] [PubMed]

122. Fabbri, M.; Paone, A.; Calore, F.; Galli, R.; Gaudio, E.; Santhanam, R.; Lovat, F.; Fadda, P.; Mao, C.; Nuovo, G.J.; et al. MicroRNAs bind to Toll-like receptors to induce prometastatic inflammatory response. Proc. Natl. Acad. Sci. USA 2012, 109, E2110-E2116. [CrossRef] [PubMed]

123. Ding, G.; Zhou, L.; Qian, Y.; Fu, M.; Chen, J.; Chen, J.; Xiang, J.; Wu, Z.; Jiang, G.; Cao, L. Pancreatic cancer-derived exosomes transfer miRNAs to dendritic cells and inhibit RFXAP expression via miR-212-3p. Oncotarget 2015, 6, 29877-29888. [CrossRef]

124. Kim, J.; Morley, S.; Le, M.; Bedoret, D.; Umetsu, D.T.; Di Vizio, D.; Freeman, M.R. Enhanced shedding of extracellular vesicles from amoeboid prostate cancer cells: Potential effects on the tumor microenvironment. Cancer Biol. Ther. 2014, 15, 409-418. [CrossRef]

125. Kogure, T.; Lin, W.L.; Yan, I.K.; Braconi, C.; Patel, T. Intercellular nanovesicle-mediated microRNA transfer: A mechanism of environmental modulation of hepatocellular cancer cell growth. Hepatology 2011, 54, 1237-1248. [CrossRef]

126. Cui, H.; Seubert, B.; Stahl, E.; Dietz, H.; Reuning, U.; Moreno-Leon, L.; Ilie, M.; Hofman, P.; Nagase, H.; Mari, B. Tissue inhibitor of metalloproteinases-1 induces a pro-tumourigenic increase of miR-210 in lung adenocarcinoma cells and their exosomes. Oncogene 2015, 34, 3640-3650. [CrossRef]

127. Teng, Y.; Ren, Y.; Hu, X.; Mu, J.; Samykutty, A.; Zhuang, X.; Deng, Z.; Kumar, A.; Zhang, L.; Merchant, M.L. MVP-mediated exosomal sorting of miR-193a promotes colon cancer progression. Nat. Commun. 2017, 8, 1-16. [CrossRef] [PubMed]

128. Senfter, D.; Holzner, S.; Kalipciyan, M.; Staribacher, A.; Walzl, A.; Huttary, N.; Krieger, S.; Brenner, S.; Jager, W.; Krupitza, G.; et al. Loss of miR-200 family in 5-fluorouracil resistant colon cancer drives lymphendothelial invasiveness in vitro. Hum. Mol. Genet. 2015, 24, 3689-3698. [CrossRef] [PubMed]

129. Yazarlou, F.; Mowla, S.J.; Oskooei, V.K.; Motevaseli, E.; Tooli, L.F.; Afsharpad, M.; Nekoohesh, L.; Sanikhani, N.S.; Ghafouri-Fard, S.; Modarressi, M.H. Urine exosome gene expression of cancer-testis antigens for prediction of bladder carcinoma. Cancer Manag. Res. 2018, 10, 5373-5381. [CrossRef] [PubMed]

130. Cui, Z.; Chen, Y.; Hu, M.; Lin, Y.; Zhang, S.; Kong, L.; Chen, Y. Diagnostic and prognostic value of the cancer-testis antigen lactate dehydrogenase C4 in breast cancer. Clin. Chim. Acta 2020, 503, 203-209. [CrossRef]

131. Kannan, A.; Philley, J.V.; Hertweck, K.L.; Ndetan, H.; Singh, K.P.; Sivakumar, S.; Wells, R.B.; Vadlamudi, R.K.; Dasgupta, S. Cancer testis Antigen promotes triple negative Breast cancer Metastasis and is traceable in the circulating extracellular Vesicles. Sci. Rep. 2019, 9, 1-12. [CrossRef] [PubMed]

132. Restifo, N.P.; Dudley, M.E.; Rosenberg, S.A. Adoptive immunotherapy for cancer: Harnessing the T cell response. Nat. Rev. Immunol. 2012, 12, 269-281. [CrossRef] [PubMed]

133. Wargo, J.A.; Robbins, P.F.; Li, Y.; Zhao, Y.; El-Gamil, M.; Caragacianu, D.; Zheng, Z.; Hong, J.A.; Downey, S.; Schrump, D.S.; et al. Recognition of NY-ESO-1+ tumor cells by engineered lymphocytes is enhanced by improved vector design and epigenetic modulation of tumor antigen expression. Cancer Immunol. Immunother. 2009, 58, 383-394. [CrossRef] [PubMed]

134. Cho, Y.W.; Kim, S.Y.; Kwon, I.C.; Kim, I.S. Complex adaptive therapeutic strategy (CATS) for cancer. J. Control. Release 2014, 175, 43-47. [CrossRef]

135. Aoki, N.; Matsui, Y. Comprehensive Analysis of Mouse Cancer/Testis Antigen Functions in Cancer Cells and Roles of TEKT5 in Cancer Cells and Testicular Germ Cells. Mol. Cell. Biol. 2019, 39. [CrossRef]

(C) 2020 by the authors. Licensee MDPI, Basel, Switzerland. This article is an open access article distributed under the terms and conditions of the Creative Commons Attribution (CC BY) license (http://creativecommons.org/licenses/by/4.0/). 